\title{
Effects of Financial Literacy on Individual Choices Among Financial Access Strands in Kenya
}

\author{
Adan Guyo Shibia, Joseph Kieyah \\ Kenya Institute for Public Policy Research and Analysis, Nairobi, Kenya \\ Email address: \\ ashibia@kippra.or.ke (A. G. Shibia), adanguyo2004@yahoo.com (A. G. Shibia), kieyah@kippra.or.ke (J. Kieyah)
}

\section{To cite this article:}

Adan Guyo Shibia, Joseph Kieyah. Effects of Financial Literacy on Individual Choices Among Financial Access Strands in Kenya. International Journal of Business and Economics Research. Vol. 5, No. 1, 2016, pp. 10-18. doi: 10.11648/j.ijber.20160501.12

\begin{abstract}
This paper investigates effects of financial literacy on individual choices among formal financial services, informal financial services, and complete financial exclusion in Kenya. The study employed cross-sectional analysis using FinAccess national surveys 2009 and 2013 for 6,598 and 6,449 individuals, respectively. Multinomial probit regressions show that financial literacy is a strong predictor of individual demand for financial services. Financial literacy scores increases with increasing level of formality and average performance on financial literacy tests is generally lower than those reported in extant studies for developed countries. The findings suggest importance of policy efforts to promote financial literacy to expand individual access to formal financial services. To our knowledge this is the first paper in developing countries context to use both objective and self-reported measures of financial literacy and its role in individual choices among different financial access strands.
\end{abstract}

Keywords: Financial Access, Literacy, Probit, Sub-saharan Africa, Kenya

\section{Introduction}

This study investigates effects of financial literacy on financial access in Kenya. Recent literature reveals that financial literacy embodies consumer's ability to process economic information in order to make informed financial decisions [1, 2, 3], thus making it imperative in financial development policy agenda. The concept of financial access encompasses credit, savings, payment, insurance and other risk-management services $[4,5]$. Access to financial services is of interests due to its impacts on development outcomes such as household welfare and economic growth [6, 7, 8]. Low access to formal financial services in Kenya mirrors pervasive problem in Sub-Saharan Africa where only one in five households has access to formal financial services [8]. The classifications of formal or informal depend on extent to which financial service providers are regulated. Formal financial products are supplied by institutions supervised by regulatory agencies while informal financial products are provided by institutions operating outside legal framework $[9,10]$.

Recent literature demonstrates importance of financial literacy in individual economic choices such as retirement planning and savings behaviour [11, 3, 12]. At macro level countries with higher financial literacy have higher savings rate [13]. While the dynamics of individual access to formal financial services in Kenya is rapidly improving as a result of payment services driven by $m$-pesa ${ }^{I}$; access to savings, credit and insurance remain low at $58 \%, 29 \%$ and $17 \%$, respectively [14]. With over $50 \%$ of adult population in Kenya demonstrating low levels of financial literacy [14], its possible effects on individual economic decisions is of policy concern. Among the individuals using any form of financial services in Kenya, only one-third use services provided by formal financial institutions supervised by regulatory agencies, notably the Central Bank of Kenya; Insurance Regulatory Authority; Capital Market Authority; Retirement Benefit Authority; and Sacco Societies Regulatory Authority [14]. Kenya's agenda to expand household access to formal financial services is anchored in the national development blueprint, Vision 2030. Perceptively, formal financial accessibility is a strategic vehicle of raising the ratio of private savings to gross domestic product from $14 \%$ to $26 \%$ [15]. Moreover, loss of savings through informal financial services is high, making its use undesirable [16]. It is therefore of interests to investigate potential role of financial literacy in individual choice among use of formal financial services, informal financial services, and total financial exclusion. 
Extant empirical studies show discrepancies between self reported (subjective) measures of financial literacy and actual performance (objective measures) on financial literacy scores [3]. However, limited empirical evidence exists on potential effects of the two measures of financial literacy on individuals' financial access choice in the context of three financial access strands: formal, informal and complete financial exclusion. This study utilizes multinomial probit regressions for both self-reported measures of financial literacy and actual performance on financial literacy test. The results suggest that both measures of financial literacy are important predictors of access to financial services.

\section{Literature Review}

\subsection{Theoretical Literature}

As suggested in recent review of literature [3] little attention has been given to advancement of theory on acquisition and deployment of financial literacy. However, insights can be borrowed from existing theories of financial exclusion. Among the traditional theories on financial exclusion include credit rationing theory [17]; and the behavioural and institutional analysis views [18]. Credit rationing theory suggests that financial institutions ration credit largely due to adverse selection and incentive problems even in situations where the borrower is willing to pay higher interest rates. Rising interest rates potentially increase the riskiness of loan portfolio either by discouraging safer borrowers or inducing borrowers to invest in risky projects [17]. Viewing information asymmetry as an increasing function of financial illiteracy and corroborating it with Akerlof's perspectives on market for lemons [19], theories on information asymmetries form foundation for role of financial literacy in financial access. Recent review of literature confirms that less financially literate individuals are prone to making financial errors [3] and borrow at high costs [20] which may require relatively higher monitoring costs. Credit rationing theory however views financial exclusion problem from supply perspectives and is limited to credit markets.

The behavioural view relaxes the assumption of consumer rationality; suggesting consumers may borrow from informal sources such as money lenders at relatively higher interest rates [18]. Such irrational behaviours can be linked to consumer's level of access to information [21]. Moreover, viewing financial literacy as a form of human capital [3] requires utility maximizing individuals to evaluate alternatives and shun high costs and risky financial services. Institutional analysis view assumes the consumer is rational but argues that changing institutional environments constrains access to financial services, either through deteriorating purchasing power of the consumer or through physical access as financial institutions relocate to profitable regions [18]. The principal demand side factors linked with institutional analysis originate primarily from increasing income inequality while supply side factors may result from market liberalization that incentivise financial institutions to shut unprofitable branches [18]. Thus, institutional view largely suggests role of budget constraints limiting consumer affordability of financial services. Another strand of theory related to the institutional analysis view is the high cost view [18] and argues that because formal financial services involve high fixed costs and hence expensive, low income individuals seek alternative credit and saving services [12]. When the gains from formal financial services is less than associated transactions costs [4] a rational consumer will chose informal financial services or may even decide to be completely excluded.

The acquisition of financial literacy can be viewed as an endogenous decision that takes the form of investment in human capital [3]. This perspective allows us to conceptualize financial literacy as stock of individual's welfare enhancing investments in skills. Though in the seminal work of human capital theory, acquisition of training and skills is postulated to foster wage growth [22] in the context of financial literacy, investments in human capital can be viewed in terms of return enhancing decision such as better performing savings and borrowing choices [3] for a utility maximizing individual.

\subsection{Empirical Literature}

Increasing complexity of financial products and the need for individuals to play more active role in personal finance motivated early research on assessment of household financial literacy levels and its role in economic decisions $[23,24,3]$. The recent global financial crisis has further amplified policy and research interests in the competency of consumers to assess risks inherent in increasingly complex financial products. The development of research on effects of financial literacy on individual economic decisions is relatively documented in developed countries compared to emerging and developing economies $[25,3,12]$ possibly due to these developments. Higher financial literacy enhances savings accumulation [26, 27, 12, 28, 1, 24, 11, 29, 30]. Higher financial literacy is also associated with greater wealth accumulation, higher probability of investing in stock market [29] and greater portfolio diversification [31]. Less financially literate households borrow at higher interest rates [20]; and are less likely to participate in formal financial systems [29].

The interests in the field was extended to emerging economies through field experiments in Indonesia and India where it was established that financial literacy stimulates demand for bank accounts [12]. Thus, growing evidence motivates policy agenda of enhancing financial literacy. Heterogeneity of financial literacy across countries and among segments of populations within countries has also attracted interests. Recent literature shows that male respondents demonstrate higher competency on financial literacy tests than female counterparts [32, 33]. Possible explanations for the observations in gender differences can be linked to specialization within households with majority of women acquiring financial literacy late in their life-cycle 
[34]. Other studies have found that the young and the old demonstrate lower levels of financial literacy [3]. Crosscountry analysis shows that countries with generous social security systems are characterized by lower levels of financial literacy while those with higher share of urban population and well developed human capital such as formal education demonstrating higher levels of financial literacy [23]. While literature reveals substantial mismatch between objective and subjective measures of financial literacy [3] the extent to which they differ in terms of impacts on economic decisions or factors contributing to the mismatch is not well documented.

Extant research has also established that control variables including socio-economic, demographic and geographical factors affect incidences of exclusion from formal financial services. Being female $[35,36]$, having low income $[37,12$, 36] and distance from bank branches [4] increase incidence of exclusion from formal financial services. On the other hand being older $[38,35,18]$ and acquisition of higher levels of formal education increases incidence of access to formal financial services [39, 40, 37, 38, 35, 41, 42, 18$]$.

\section{Methodology}

\subsection{Conceptual Framework}

Demand for financial services is driven by economic factors including price and income; as well as non-economic factors such as financial illiteracy and socio-cultural factors [43]. Within the budget constraints, tastes and preferences such as inter-temporal choice and liquidity requirements shape the demand curve [44]. An individual purchases financial product if the marginal utility exceeds marginal costs; that is: $u_{i}$ (financial product) $-p_{i}>0$ where $p$ represents discounted costs of financial products such as transaction fees, borrowing costs, and loan maturity where liquidity constraints exists [45]. Following extant studies [43], we hypothesize two demand curves, one solely driven by economic factors such as price and income (D); and the other driven by a combination of economic factors and financial illiteracy $\left(D^{*}\right)$. Thus we have $D=f(X)-D^{*}=f(X$, financial illiteracy) $>0$; where $\mathrm{X}$ is a vector of economic factors. Consumer access to information and product features can shift demand for a product $[45,21]$ which can be viewed as a direct impact on utility. Further evidence demonstrates that less financially literate individuals borrow at high costs and make more financial errors [20] such that $p_{i}$ increases, possibly due to more monitoring by a utility maximizing individual. Demand can therefore be viewed as an increasing function of income but a decreasing function of price and financial illiteracy; thus creating a possibility whereby actual demand is lower than potential demand attributable to economic factors [43].

\subsection{Econometric Model}

We use a discrete choice model derived in a random utility model framework. The discrete choice model assumes individuals maximize utility in making choice decision [46, 47]. The basic framework is that an individual $n$ faces $J$ alternatives with each choice providing certain level of utilities known to the decision-maker. An individual makes choice $i$ iff $u_{n i}>u_{n j} \forall j \neq i$ [47]. We however do not observe the utility provided by each alternative, but instead observe some characteristics of the alternatives and the decision-maker. We thus categorize the choices into three financial access strands: formal, informal and financially excluded. The definition of financial access strand varies with country depending on structure of the financial sector. To facilitate comparison with similar studies in other countries, definition of formal access strand [48] was adopted but commercial banks, PostBank, non-insurance companies, Savings and Credit Cooperative Societies (SACCOs) and Microfinance Institutions (MFIs) were categorised together as formal. Ongoing reforms in Kenya to formalize SACCOs and MFIs necessitate their categorization as formal institutions for brevity of analysis. On the other hand we group ASCAs, RoSCAs ${ }^{2}$ and other informal groups as informal financial services. Individuals lacking access to at least informal services are categorized as excluded. In situations where a respondent uses multiple services that rank at different access strands, the most formal access strand classification is assigned $[49,39]$. Thus, each respondent is placed in a single and mutually exclusive category of financial access strand dependent on most formal financial service they use.

On the basis of these categorizations, alternative with the highest pay-off (utility) is chosen and we only observe the alternative that is chosen. If individual $n$ makes choice $j$ in particular, then we assume that utility $u_{i j}$ is the maximum among $j$ utilities. The statistical model is driven by the probability that choice $j$ is made, which is $\operatorname{Prob}\left(\mathrm{u}_{\mathrm{ni}}>\mathrm{u}_{\mathrm{nj}}\right)$ for all other $\mathrm{i} \neq \mathrm{j}$ alternatives. Category $\mathrm{j}$ is chosen if the underlying latent $y_{i j}^{*}$ is highest for $\mathrm{j}$, that is

$$
y_{i}=\left\{\begin{array}{c}
y_{j}^{*}=\max \left[y_{1}^{*}, y_{2}^{*}, y_{3}^{*}\right] \\
0 \text { othersise }
\end{array}\right.
$$

We assign 1 for formal financial services; 2 for informal financial services; and 3 for financially excluded category. We then run three multinomial probit regressions. In the first case, we use an index of self reported measures of financial literacy as the explanatory variable of interest, using the 2009 survey data. In the second and third regression we use ability to solve basic numeracy and interest rates problems, respectively using the 2013 survey data. The self reported measures of financial literacy were not available in the 2013 data set to facilitate use of single data set, or to facilitate comparison.

\subsection{Data and Data Sources}

The study utilized data for the Finaccess 2009 and 2013 surveys $[50,51]$ for adult individuals who are $18+$ years. The FinAccess surveys are individual-level surveys to understand socio-economic and geographic barriers to financial inclusion and exclusion [52, 14]. The surveys 
capture access to both formal and informal financial services. The sampling was undertaken by the Kenya National Bureau of Statistics (KNBS) while the field work was conducted by two market research companies; TNS-RMS for the 2013 survey and Synovate for the 2009 survey. Both surveys used cluster stratified probability sampling. In the first stage clusters were selected to facilitate representation at national level $[52,14]$. In the second stage households were selected within each cluster; while the in the third stage individuals were selected from households using KISH grid to randomly select a respondent aged $16+$ years $^{3}$. The 2009 survey achieved 6,598 completed interviews [52] while the 2013 survey achieved 6,449 completed interviews [14]. Respondents below the age of 18 were excluded from the analysis because of legal age restrictions to enter into binding legal arrangements with financial institutions. Financial institutions require identification documents such as national identity cards and respondents below the age of 18 usually lack such documents.

\subsection{Variable Definitions and Measurements}

For the first regression for which we use the 2009 dataset, financial literacy is computed as an index from a set of 16 questions used to assess self-reported knowledge about financial concepts and products. The scores were awarded as follows: 1 = have never heard of the concept or product; $2=$ have heard of the concept or product but does not understand what it means; 3 = have heard of the concept or product and knows what it means. The financial literacy index thus ranges between zero (for reporting 'never heard of the concept or product' for all the 16 items) and 48 (reporting 'have heard and knows what the concept or product means' for all the 16 items). The concepts include savings account, insurance, interest rate, shares, cheque, collateral, ATM card, credit card, budget, investment, inflation, leasing, pension, mortgage, pyramid schemes, and credit bureaus.

The 2013 survey included two questions that investigated the ability of the respondent to answer two financial calculations correctly. The numeracy question is posed as follows: "You are in a group and win a promotion or competition for Ksh. 100,000. With five of you in the group, how much do each of you get?" The second question on interest rate is posed as follows: "You take a loan of Ksh. 10,000 with an interest rate of $10 \%$ a year. How much interest would you have to pay at the end of the year?" In both questions the responses are recorded as "correct", "incorrect", or "don't know".

Control variables include a continuous age variable, income as proxied by respondent's total monthly consumption expenditure, a binary region variable $(1=$ urban, $0=$ rural), categorical variable for proximity to reach nearest bank branch to proxy for distance to formal financial institutions $(1=$ Less than 30 minutes; $2=30$ minutes 1hour; $3=2-3$ hours; $4=4-5$ hours; $5=6+$ hours), a dummy gender variable $(1=$ male; $0=$ female $)$, and a categorical education variable $(1=$ No formal education; $2=$ primary education; 3 = secondary education; 4 = tertiary education).
For numeracy and interest rate literacy variables, correct answer is coded 1 , zero otherwise.

\subsection{Test of Financial Literacy Endogeneity}

Despite efforts to enhance financial access through enhanced financial literacy, questions still linger on possibility of endogeneity biases [53]. Individuals who lack financial access may also be financially illiteracy due to measurement error and underlying unobservables [25]. To evaluate the possibility of endogeneity, we use the number of household income earners as an instrument for self reported measures of financial literacy. The choice of the instrument is motivated by social learning as a means for financial literacy acquisition [54]. We assume financial experience of other household members to be exogenous with respect to a respondent's actions to belong to a particular financial access strand which is driven by individual utility maximization. However, financial experiences of other household members create an environment where one is exposed to financial literacy through social interactions [54]. We lack additional or alternative excluded instrument with the available data set. The 2013 survey does not include the number of household income earners, and for lack of an alternative instrument variable, we are not able to test for endogeneity. Recent survey of literature shows that instrumental variable estimates are generally larger than non-instrumented estimates [3] possibly indicating underestimation of the effects by the latter. A shortcoming of prior studies that use instrumental variable estimates is that they do not report if they tested for presence of endogeneity. Recent survey of literature provides excellent summary of extant studies that have used instrumental variables [3]. Use of instruments in the absence of endogeneity can however worsen the results [55].

To test for endogeneity, we use two-stage residual inclusion (2SRI), also known as control function approach. In the first stage, we regress financial literacy index on both included and excluded instruments. In the second stage, we include the first stage residual as an additional explanatory variable in the structural regression. For non-linear models the Two-Stage Residual Inclusion (2SRI) produce superior consistent estimates compared to the Two-Stage Predictor Substitution (2SPS) in addressing endogeneity [56]. The coefficient of the first stage residual in the structural regression was insignificant, implying there is no sufficient evidence of endogeneity problem. Thus, we run the regression without using instrumental variable.

Some insights on quality of the instrumental variable worth mention. The partial $\mathrm{R}^{2}$ and F-Statistics of the excluded instruments in the first-stage estimation are important indicators of quality of the instrumental variable estimates and should therefore be reported [55]. The partial $\mathrm{R}^{2}$ and F-statistic are obtained by partialling out the included instruments [55]. The partial F-statistic is a reliable measure of instrument relevance if there is only one endogenous variable while Shea's partial $\mathrm{R}^{2}$ is designed to account for multiple endogenous regressors [57]. As a rule of the thumb, if the standard $R^{2}$ is high and the Shea's partial $R^{2}$ is low, 
instruments lack sufficient relevance $[58,59]$. The partial $\mathrm{R}^{2}$ and F-statistic using the number of household income earners as instrument are respectively $0.38 \%$ and 15.34 . The partial F-statistic in the first-stage regression is high (15.34) and exceeds the recommended value of 10 [60] indicating that the instrument is sufficiently correlated with the suspect endogenous variable. The coefficient of household income earners is positive and significant at 5\% significance level in the first stage regression.

\section{Results and Discussions}

\subsection{Descriptive Statistics}

Table 1 shows summary statistics for financial literacy across the formal, informal and excluded categories. It is notable that the mean of the financial literacy declines with decreasing level of formality. For the 2009 survey individuals with formal financial access have a mean financial literacy index of 39.07 while those who are excluded have least financial literacy index of 27.80. However, the standard deviation of financial literacy index across the access strands increases with decreasing level of formality, an indication of increasing disparities of financial literacy among those who are financially excluded. Similar observations are made for the 2013 survey, for both numeracy and interest test scores. Comparing numeracy and interest literacy, scores on the latter are generally low across the three categories. While $70 \%$ of the respondents answered numeracy question correctly, only $53 \%$ correctly answered the question on interest rate. Only $43 \%$ of the financially excluded individuals correctly answered the question on interest rate, compared to $58 \%$ for numeracy test.

Table 1. Summary statistics.

\begin{tabular}{lccc}
\hline Access Strand & Frequency & Mean & \multicolumn{1}{c}{ Standard Deviation } \\
\hline \multicolumn{2}{l}{ Summary statistics } & for financial & literacy index, 2009 \\
Formal & 2,706 & 39.07 & 7.54 \\
Informal & 1,720 & 29.34 & 7.93 \\
Excluded & 1,903 & 27.80 & 8.79 \\
Total & 6,329 & 33.04 & 9.60 \\
Summary Statistics for Numeracy & Literacy, 2013 & \\
Formal & 2,130 & 0.84 & 0.37 \\
Informal & 975 & 0.65 & 0.48 \\
Excluded & 2,056 & 0.58 & 0.49 \\
Total & 5,161 & 0.70 & 0.46 \\
Summary Statistics & Interest Literacy, 2013 & \\
Formal & 1909 & 0.65 & 0.48 \\
Informal & 802 & 0.44 & 0.50 \\
Excluded & 1658 & 0.43 & 0.49 \\
Total & 4,369 & 0.53 & 0.50 \\
\hline
\end{tabular}

Data source: Finaccess (2009a) and Finaccess (2013b)

In light of extant empirical work, performance on interest rate scores is lower compared to developed countries though the questions were not formulated exactly the same ${ }^{4}$. For instance, in the US $67.1 \%$ of the respondents correctly answered questions on compound interest [3] while in Netherlands $84.8 \%$ correctly answered the question [61]. In
Japan $70.5 \%$ correctly answered question on interest rate [62].

\subsection{Regression Results}

In this section we present multinomial probit regression marginal effects, using 'excluded' category as the base outcome. Version 13 of Stata was used for the analysis. The result shows that both objective and subjective measures of financial literacy are strong predictors of financial access. The marginal effects for financial literacy for formal financial access are statistically significant $(p<0.01)$ for the three regressions. For the first regression, a unit increase in financial literacy index increases the probability of access to formal and informal financial access by about $8 \%$ and $2 \%$ higher respectively, compared to the financially excluded category. The relatively lower magnitude for informal access strand compared to the base outcome reflects decreasing level of financial literacy with decreasing level of formality. For the numeracy question, individuals who correctly scored on the test have about $47 \%$ and $8 \%$ higher probability of access to formal and informal financial services, relative to the base outcome. For the interest question, individuals who correctly scored on the test have about $21 \%$ higher probability of access to formal financial services, relative to the base outcome. The results are consistent with growing international evidence linking financial literacy to important economic decisions such as borrowing, saving and retirement planning behaviours [3]. The results suggest the need for promoting financial literacy policies as a strategy for lowering financial exclusion among the adult population.

The control variables also significantly affect choice of access strands. The coefficient of age is positive and being older increases the probability of formal access across the three regressions. This is consistent with extant literature [38, $35,18]$. Being older by one year increases the probability of access to formal financial services by $2 \%$ for self reported financial literacy, and about $1 \%$ for both numeracy and interest literacy, compared to the excluded category. Younger individuals are more likely to self exclude, choosing to consume their financial resources rather than defer them for future consumption [38]. From the perspective of formal financial institutions, these findings have important implications in terms of products that induce younger individuals defer current consumption in favour of future consumption. Efforts to develop youth development accounts at early age to inculcate savings culture are imperative in increasing younger individuals' access to financial services. Access to formal financial services at younger age is critical for accumulating savings and building stock of credit information over lifecycle. However, being older by one year increases informal access by $0.8 \%$ higher for self reported measures, compared to the base category.

The marginal effect for income is also statistically significant $(\mathrm{p}<0.01)$ for formal and informal categories. Such resource exclusion has implications for intervention policies aimed at removing households from poverty. The marginal effect for region is positive and statistically significant for the formal outcome and being urban increases probability of 
access to formal financial services by $16.6 \%$ higher for self reported measures, compared to the base outcome. Intriguingly, for the third regression, being urban lowers formal access by about $13 \%$. The result can be explained by inclusion of SACCOs and MFIs in formal access strand. SACCOs and MFIs are dominant in rural areas [63]. Being rural or urban does not affect the choice of being informal or excluded. However, this contrast with prior studies which finds that while region does not affect access to formal financial services, being rural significantly lowers likelihood of being completely excluded through semi-formal and informal services [35]. This is attributable to historical dominance of agricultural-based SACCOs in rural areas [35]. The contrast in effect of region on formal financial access could be due to their inclusion of another region variable, province [35], which may have had dominating effects ${ }^{5}$.

The marginal effect for gender is also significant with regards to demand for formal and informal categories using self reported measures. Male individuals are however less likely to be formally and informally included. This is surprising and contrasts prior findings [35], but can be explained by inclusion of SACCOs and MFIs in formal category in line with ongoing institutional reforms. Women's higher access to informal financial services is linked to their historical dominance of informal groups such as ROSCAS and their strong social ties [63]. Education is also important determinants of demand for financial services, suggesting importance of human capital development. Individuals with formal education are generally more likely to be formally and informally included. Proximity to formal financial institutions is also important determinant of financial access. Those who spend longer hours to reach formal institutions are more likely to be excluded.

Table 2. Multinomial Probit Regression Marginal Effects.

\begin{tabular}{|c|c|c|c|c|c|c|}
\hline \multirow[b]{3}{*}{ VARIABLES } & \multicolumn{2}{|c|}{2009 FinAccess Survey } & \multicolumn{4}{|c|}{2013 FinAccess Survey } \\
\hline & \multicolumn{2}{|c|}{ Self reported financial literacy (1) } & \multicolumn{2}{|c|}{ Numeracy literacy (2) } & \multicolumn{2}{|c|}{ Interest literacy (3) } \\
\hline & formal & informal & formal & informal & formal & informal \\
\hline Financial Literacy & $\begin{array}{l}0.0795 * * * \\
(0.00431)\end{array}$ & $\begin{array}{l}0.0195 * * * \\
(0.00423)\end{array}$ & $\begin{array}{l}0.469 * * * \\
(0.0680)\end{array}$ & $\begin{array}{l}0.0756 \\
(0.0694)\end{array}$ & $\begin{array}{l}0.210 * * * \\
(0.0657)\end{array}$ & $\begin{array}{l}-0.0958 \\
(0.0713)\end{array}$ \\
\hline Age & $\begin{array}{l}0.0219 * * * \\
(0.00198)\end{array}$ & $\begin{array}{l}0.00822 * * * \\
(0.00187)\end{array}$ & $\begin{array}{l}0.0102 * * * \\
(0.00152)\end{array}$ & $\begin{array}{l}0.000780 \\
(0.00170)\end{array}$ & $\begin{array}{l}0.00945 * * * \\
(0.00165)\end{array}$ & $\begin{array}{l}-0.000248 \\
(0.00185)\end{array}$ \\
\hline Income & $\begin{array}{l}2.69 \mathrm{e}-05 * * * \\
(2.75 \mathrm{e}-06)\end{array}$ & $\begin{array}{l}4.24 \mathrm{e}-06 \\
(3.34 \mathrm{e}-06)\end{array}$ & $\begin{array}{l}4.20 \mathrm{e}-05 * * * \\
(3.24 \mathrm{e}-06)\end{array}$ & $\begin{array}{l}2.42 \mathrm{e}-05 * * * \\
(3.49 \mathrm{e}-06)\end{array}$ & $\begin{array}{l}4.13 \mathrm{e}-05 * * * \\
(3.40 \mathrm{e}-06)\end{array}$ & $\begin{array}{l}2.41 \mathrm{e}-05 * * * \\
(3.67 \mathrm{e}-06)\end{array}$ \\
\hline Region: Urban & $\begin{array}{l}0.166^{* *} \\
(0.0757)\end{array}$ & $\begin{array}{l}-0.0179 \\
(0.0797)\end{array}$ & $\begin{array}{l}-0.0996 \\
(0.0650)\end{array}$ & $\begin{array}{l}0.0627 \\
(0.0708)\end{array}$ & $\begin{array}{l}-0.132 * \\
(0.0705)\end{array}$ & $\begin{array}{l}0.0287 \\
(0.0779)\end{array}$ \\
\hline Proximity: 30 min-1 hour & $\begin{array}{l}-0.140 * * \\
(0.0691)\end{array}$ & $\begin{array}{l}0.176 * * \\
(0.0697)\end{array}$ & $\begin{array}{l}-0.174 * * \\
(0.0684)\end{array}$ & $\begin{array}{l}0.0136 \\
(0.0725)\end{array}$ & $\begin{array}{l}-0.107 \\
(0.0745)\end{array}$ & $\begin{array}{l}0.0824 \\
(0.0800)\end{array}$ \\
\hline Proximity: $2-3$ hours & $\begin{array}{l}-0.332 * * * \\
(0.0882)\end{array}$ & $\begin{array}{l}0.144 * \\
(0.0839)\end{array}$ & $\begin{array}{l}-0.465^{* * *} \\
(0.113)\end{array}$ & $\begin{array}{l}-0.0665 \\
(0.113)\end{array}$ & $\begin{array}{l}-0.560 * * * \\
(0.126)\end{array}$ & $\begin{array}{l}-0.0712 \\
(0.126)\end{array}$ \\
\hline Proximity: $4-5$ hours & $\begin{array}{l}-0.567 * * * \\
(0.207)\end{array}$ & $\begin{array}{l}-0.286 \\
(0.175)\end{array}$ & $\begin{array}{l}-0.783 * \\
(0.414)\end{array}$ & $\begin{array}{l}-0.0448 \\
(0.359)\end{array}$ & $\begin{array}{l}-1.009 * * \\
(0.477)\end{array}$ & $\begin{array}{l}0.226 \\
(0.392)\end{array}$ \\
\hline Proximity: $6+$ hours & $\begin{array}{l}-1.582 * * * \\
(0.287)\end{array}$ & $\begin{array}{l}-1.051^{* * *} \\
(0.192)\end{array}$ & $\begin{array}{l}-0.779 \\
(0.485)\end{array}$ & $\begin{array}{l}-0.460 \\
(0.458)\end{array}$ & $\begin{array}{l}-1.092 * \\
(0.562)\end{array}$ & $\begin{array}{l}-0.749 \\
(0.532)\end{array}$ \\
\hline Gender: Male & $\begin{array}{l}-0.164 * * * \\
(0.0591)\end{array}$ & $\begin{array}{l}-0.506^{* * *} \\
(0.0595)\end{array}$ & $\begin{array}{l}0.0311 \\
(0.0590)\end{array}$ & $\begin{array}{l}-0.528 * * * \\
(0.0655)\end{array}$ & $\begin{array}{l}0.0808 \\
(0.0640)\end{array}$ & $\begin{array}{l}-0.492 * * * \\
(0.0717)\end{array}$ \\
\hline Education: Primary & $\begin{array}{l}0.762 * * * \\
(0.0961)\end{array}$ & $\begin{array}{l}0.552 * * * \\
(0.0820)\end{array}$ & $\begin{array}{l}0.617 * * * \\
(0.130)\end{array}$ & $\begin{array}{l}0.435 * * * \\
(0.125)\end{array}$ & $\begin{array}{l}0.804 * * * \\
(0.145)\end{array}$ & $\begin{array}{l}0.486 * * * \\
(0.137)\end{array}$ \\
\hline Education: Secondary & $\begin{array}{l}1.101 * * * \\
(0.118)\end{array}$ & $\begin{array}{l}0.196 * \\
(0.111)\end{array}$ & $\begin{array}{l}1.187 * * * \\
(0.137)\end{array}$ & $\begin{array}{l}0.408^{* * *} \\
(0.135)\end{array}$ & $\begin{array}{l}1.353 * * * \\
(0.151)\end{array}$ & $\begin{array}{l}0.424 * * * \\
(0.147)\end{array}$ \\
\hline Education: Tertiary & $\begin{array}{l}1.529 * * * \\
(0.182)\end{array}$ & $\begin{array}{l}-0.397 * \\
(0.239)\end{array}$ & $\begin{array}{l}2.261 * * * \\
(0.180)\end{array}$ & $\begin{array}{l}0.511 * * \\
(0.203)\end{array}$ & $\begin{array}{l}2.431 * * * \\
(0.193)\end{array}$ & $\begin{array}{l}0.495 * * \\
(0.217)\end{array}$ \\
\hline Constant & $\begin{array}{l}-4.154 * * * \\
(0.183)\end{array}$ & $\begin{array}{l}-1.217 * * * \\
(0.164)\end{array}$ & $\begin{array}{l}-1.734 * * * \\
(0.156)\end{array}$ & $\begin{array}{l}-0.942 * * * \\
(0.155)\end{array}$ & $\begin{array}{l}-1.608^{* * *} \\
(0.172)\end{array}$ & $\begin{array}{l}-0.826^{* * *} \\
(0.170)\end{array}$ \\
\hline Observations & 6,094 & 6,094 & 4,796 & 4,796 & 4,067 & 4,067 \\
\hline
\end{tabular}

Data source: Finaccess (2009a) and Finaccess (2013b) *** $\mathrm{p}<0.01, * * \mathrm{p}<0.05, * \mathrm{p}<0.1$ Standard errors in parentheses

\section{Conclusion}

Access to financial services plays important role in individual development outcomes by smoothening consumption and easing credit constraints. This study has established that financial literacy, as measured by both selfreported measures and actual performance on test scores, are strong predictors of financial access in Kenya. Individuals with access to formal financial services demonstrate higher literacy scores compared to those using informal financial services. Individuals who are financially excluded demonstrate least financial literacy scores. The findings suggest that to realize financial access for majority of the individuals in Kenya, public policy should aim at enhancing financial literacy to complement price reduction interventions. Given that individuals who are financially excluded demonstrate least financial literacy scores, more policy efforts should be geared towards this segment of the market. Future research can extend current work by evaluating cost-effective options for delivering financial literacy programs; as well as investigating factors 
contributing to discrepancies between objective and subjective measures of financial literacy.

\section{References}

[1] G. T. Kefela, "Promoting access to finance by empowering consumers: Financial literacy in developing countries," pp. 205-212, 2010.

[2] M. A. Wolfe-Hayes, "Financial literacy and education: An environmental scan," The International Information and Literacy Review, vol. 42, pp. 105-110, 2010.

[3] A Lusardi and Olivia S Mitchell, "The economic importance of financial literacy: Theory and evidence," Journal of Economic Literature, vol. 52, no. 1, pp. 5-44, 2014.

[4] T Beck, Ai Demirgüç-Kunt, and M Peria, "Reaching out: Access to and use of banking services across countries," Journal of Financial Economics, vol. 85, pp. 234-266, 2007.

[5] A Demirgüç-Kunt, T Beck, and P Honohan, "Finance for all? Policies and pitfalls in in expanding access," Washington, DC, 2008.

[6] O Galor and J. Zeira, "Income distribution and macroeconomics," Review of Economic Studies, vol. 60, pp. 35-52, 1993.

[7] Ross Levine, "Finance \& growth: Theory \& evidence," in Handbook of economic growth. Amsterdam: Elsevier, 2005, pp. 865-934.

[8] Patrick Honohan and Thorsten Beck, Making finance work for Africa. Washington, DC: World Bank, 2007.

[9] P Honohan and M King, "Cause and effect of financial access: Cross country evidence from the Finscope Surveys," in Banking the World. Cambridge: MIT Press, 2012, pp. 45-84.

[10] M. S Kimenya and N. S. Ndung'u, Expanding the financial services frontier: Lessons from mobile phone banking in Kenya. Washington, DC : Brookings Institute, 2009.

[11] A Lusardi and Olivia S Mitchell, "Financial literacy and retirement planning: New evidence from the rand American life panel," Michigan, Working Paper No. 2007-157 $2007 \mathrm{~b}$.

[12] Shawn Cole, Thomas Sampson, and Bilal Zia, "Prices or knowledge? What drives demand for financial services in emerging markets," Journal of Finance, vol. LXVI, no. 6, pp. 1933-1967, 2011

[13] T Jappelli and M Padula, "Investment in financial literacy and saving decisions," Napoli, CSEF working paper 2722011.

[14] Finaccess, "Finaccess national survey 2013: Profiling developments in financial access and usage in Kenya," Nairobi, 2013a.

[15] Republic of Kenya, Kenya vision 2030: A globally competitive and prosperous Kenya. Nairobi: Ministry of planning and national development, 2007.

[16] M Malkamaki, "Informality and market development in Kenya's financial sector," in Financial Inclusion in Kenya: Survey results and analysis from finaccess 2009. Nairobi: Financial Sector Deepening Kenya , 2011, pp. 67-87.
[17] J E Stiglitz and A Weiss, "Credit rationing in markets with imperfect information," The American Economic Review, vol. 71, no. 3, pp. 393-410, 1981.

[18] W Simpson and J Buckland, "Examining evidence of financial and credit exclusion in Canada from 1995 to 2005," The Journal of Socio-Economics, vol. 38, pp. 966-976, 2009.

[19] George A Akerlof, "The market for lemons: Quality uncertainty and the market mechanism," The Quarterly Journal of Economics, vol. 84, no. 3, pp. 488-500, 1970.

[20] Annamaria Lusardi and Peter Tufano, "Debt literacy, financial experience, and over-indebtedness," Cambridge, NBER working paper no. 148082009.

[21] J Stiglitz and C Walsh, Economics, 4th ed. New York: Norton and compaly ltd, 2006.

[22] Gary S Becker, Human capital: A theoretical and empirical analysis with special reference to education, 3rd ed. Chicago: The university of Chicago press, 1993.

[23] T Jappelli, "Economic literacy: An international comparison," The Economic Journal, vol. 120, pp. F429-F451, 2010.

[24] [24]A Lusardi and Olivia S Mitchell, "Baby boomer retirement security: The roles of planning, financial literacy and housing wealth," Journal of Monetary Economics, vol. 54, pp. 205-224, 2007a.

[25] J R Behrman, O S Mitchell, C Soo, and D Bravo, "Financial literacy, schooling and wealth accumulation," Cambridge, NBER working paper no. 164522010.

[26] J Ameriks, A Caplin, and Lealy J, "Wealth accumulation and propensity to plan," The Quarterly Journal of Economics, vol. 118, no. 3, pp. 1007-1047, 2003.

[27] B D Bernheim and D M Garret, "The effects of financial education in the workplace: Evidence from a survey of households," Journal of Public Economics, vol. 87, pp. 14871519,2003

[28] T Dvorak and H Hanley, "Financial literacy and design of retirement plans," The Journal of Socio-Economics, vol. 39, pp. 645-652, 2010.

[29] M. van Rooij, A. Lusardi, and R. Alessi, "Financial literacy and stock market participation," Journal of Financial Economics, vol. 101, pp. 449-472, 2011a.

[30] M van Rooij, A Lusardi, and R Alessi, "Financial literacy and retirement planning in Netherlands," Journal of Economic Pyschology, vol. 32, pp. 593-608, 2011 b.

[31] L Calvet, J Campbell, and P Sodini, "Measuring the financial sophistication of households," American Economic Review, vol. 99, pp. 393-398, 2009.

[32] Steven Agnew and Neil Harrison, "Financial literacy and student attitudes to debt: A cross-national study examining the influence of gender on personal finance concepts," Journal of Retailing \& Consumer Services, vol. 25, pp. 122-129, 2015.

[33] A C G Potrich, K M Vieira, D A Coronel, and R B Filho, "Financial literacy in Southern Brazil: Modeling and invariance between genders," Journal of Behavioral \& Experimental Finace, vol. 6, pp. 1-12, 2015.

[34] J W Hsu, "Aging \& strategic learning: The impact of spousal incentives on financial literacy," 2011. 
[35] S Johnson and M Nino-Zararua, "Financial exclusion in Kenya: An analysis of financial service use," Nairobi , 2009.

[36] J M Hogarth and K H O'Donnell, "Being accountable: A descriptive study of unbanked households in the US," in Proceedings of the association for financial couneling and planning education, Washington, DC, 1997, pp. 58-67.

[37] J Buckland and X Dong, "Banking on the margin in Canda," Economic Development Quarterly, vol. 22, no. 3, pp. 252-263, 2008.

[38] J F Delvin, "A detailed study of financial exclusion in the UK," Journal of Consumer Policy, vol. 28, pp. 75-108, 2005.

[39] T Beck et al., "Banking sector stability, efficiency and outreach," in Kenya Policies for Prosperity. Oxford: Oxford University Press, 2010, pp. 329-361.

[40] M Bendig, L Giesbert, and S Steiner, "Savings, credit and insurance: Household demand for formal financial services in rural Ghana," Manchester, Brooks world poverty institute working paper no. 762009.

[41] B Kiiza and G Pederson, "Household financial savings mobilization: Empirical evidence from Uganda," Journal of African Economies, vol. 10, no. 4, pp. 390-409, 2002.

[42] A Kumar, T Beck, C Campos, and S Chattopadhyah, "Assessing financial access in Brazil," Washington, DC, World Bank working paper no. 502005.

[43] T Beck and A de la Torre, "The basic analytics of access to financial services," Washington, DC, World Bank policy research paper no. 40262006.

[44] K E Case, R C Fair, and S M Oster, Principles of Economics, 10th ed. Boston: Prentice Hall, Inc., 2009.

[45] M Bertrand, D S Karlan, S Mullainathan, E Shafir, and J Zinman, "What's advertising content worth? Evidence from a consumer credit marketing field experiment," Quarterly Journal of Economics, vol. 125, no. 1, pp. 263-306, 2010.

[46] W H Greene, Econometric analysis, 6th ed. New Jersey: Pearson education, inc., 2008.

[47] Kenneth E Train, Discrete choice methods with simulation, 2nd ed. Cambridge: Cambridge University Press, 2009.

[48] D Porteous, Financial service access and usage in southern and east africa: What do finscope surveys tell us? Johannesburg: Finmark trust south africa, 2007.

[49] Susan Johnson and Steven Arnold, "Financial exclusion in Kenya: Examining the changing picture 2006-2009," in Financial inclusion in Kenya: Survey results and analysis from finaccess 2009. Nairobi: Financial Sector Deepening Kenya/Central Bank of Kenya, 2011, pp. 88-117.

[50] Finaccess, "Finaccess national survey 2009 data," Nairobi, Survey data 2009 a.

[51] FinAccess, "FinAccess national survey 2013 data," Nairobi, $2013 b$.

[52] FinAccess, "FinAccess national survey 2009: Dynamics of Kenya's changing financial landscape," Nairobi , 2009b.

[53] A Lusardi, O Mitchell, and V Curto, "Financial literacy among the young: Evidence and implications for consumer policy," Journal of Consumer Affairs, vol. 44, no. 2, pp. 358-380, 2010.
[54] Marie-Eve Lachance, "Financial literacy and neighborhood effects," Journal of Consumer Affairs, pp. 251-273, 2014.

[55] J Bound, D A Jaeger, and R M Baker, "Problems with instrumental variables estimation when the correlation between the instruments and the endogenous explanatory variable is weak," Journal of the American Statistical Association, vol. 90, no. 430, pp. 443-450, 1995.

[56] J V Terza, A Basu, and P J Rathouz, "Two stage residual estimation: Addressing endogeneity in health econometrics modelling," Journal of health economics, vol. 27, pp. 531543, 2008.

[57] F Carmignani, "The distributive effects of institutional quality when government stability is endogenous," European Journal of Political Economy, vol. 25, pp. 409-421, 2009.

[58] C. Baum, M. Schaffer, and S. Stillman, "Instrumental variables and GMM: Estimation and testing," Stata Journal, vol. 3, pp. 1-31, 2003.

[59] C Baum, M Schaffer, and S Stillman, "Enhanced routines for instrumental variables/generalized method of moments estimation and testing," Stata Journal , vol. 7, no. 4, pp. 465506, 2007.

[60] D Staiger and J Stock, "Instrumental variables regression with weak instruments," Econometrica, vol. 65, no. 3, pp. 557-586, 1997.

[61] Rob Alessie, Maarten Van Rooij, and Annamaria Lusardi, "Financial literacy \& retirement preparation in the Netherlands," Journal of Pension Economics \& Finance, vol. 10, no. 4, pp. 527-545, 2011.

[62] Shizuka Sekita, "Financial literacy \& retirement planning in Japan," Journal of Pension Economics \& Finance, vol. 10, no. 4, pp. 637-56, 2011.

[63] Susan Johnson, "Gender norms in financial markets: Evidence from Kenya," World Development, vol. 32, no. 8, pp. 13551374, 2004.

[64] Thorsten Beck and Asli Demirgüç-Kunt, "Access to finance: An unfinished agenda," The World Bank Economic Review, vol. 22, no. 3, pp. 383-396, 2008.

[65] D. L Remund, "Financial literacy explicated: The case for a clearer definition in an increasingly complex economy," The Journal of Consumer Affairs, vol. 44, pp. 276-295, 2010.

[66] R King and R Levine, "Finance, entrepreneurship and growth: Theory and evidence," Journal of Monetary Economics, vol. 32, pp. 513-542, 1993.

[67] S Peachey and A Roe, Access to finance: A study of the World Savings Banks Institute. Brussels: Oxford Policy Management, 2004.

[68] T. Beck and M. Fuchs, "Structural issues in the Kenyan financial system: Improving competition and access," Washington, DC, World Bank policy research paper No. 3363 2004.

[69] N S Ndung'u and R W Ngugi, "Banking sector interest rate spread in Kenya," Nairobi , KIPPRA discussion paper No. 5 2000 .

[70] R W. Ngugi, "Determinants of interest spread in Kenya ," Nairobi , KIPPRA discussion paper no. 412004. 
[71] J Oduor, S Karingi, and S Mwaura, "Efficiency of the financial market intermediation process in Kenya: A comparative analysis," Nairobi, KIPPRA discussion paper no. 1222010

[72] KIPPRA, "Legal and other constraints on access to financial services in Kenya: Survey reports," Nairobi , KIPPRA special report 2001.

[73] I W Mwangi and M M. Sichei, "Determinants of access to credit by individuals in Kenya: A comparative analysis of of the Kenya nationa finaccess surveys of 2006 and 20091 ," European Journal of Business and Management, vol. 3, pp. 206-226, 2011.

[74] R. Masa, "Kenya country assessment for youth development accounts," Washington, DC, Publication no. 09-45 2009.

[75] Kenya National Bureua of Statistics, Economic survey 2014. Nairobi : Kenya National Bureau of Statistics , 2014.

[76] T Cook, "Equity building society: scaling up microfinance in Kenya ," in Attacking Africa's poverty: Experience from the ground. Washington, DC: The World Bank , 2006, pp. 177194.

[77] Rose W Ngugi, "An empirical analysis of interest rates in Kenya," Nairobi, AERC report no. 1062001

[78] S G Beverly and M Sherraden, "Institutional determinants of saving: Implications for low income housholds and public policy," Journal of Socio-Economics, vol. 28, pp. 457-473, 1999.

1 M-Pesa is a mobile money transfer service operated by Safaricom Ltd., the largest Mobile Phone Service Operator by subscriber base in Kenya.

2 While Rotating Savings \& Credit Associations (RoSCAs) and Accumulated Savings \& Credit Associations (ASCAs) are similar in that both are voluntary groups with their own rules; in the latter members save and borrow with interest, while in the former, contributions are immediately shared among one or more members [16].

3 The KISH grid, named after the statistician Leslie Kish uses a pre-assigned table of random numbers for randomly selecting members within a household [86]

4 Recent survey of literature [3] provides the commonly used question as follows: "Suppose you had $\$ 100$ in a savings account and the interest rate was $2 \%$ per year, after 5 years how much do you think you would have in the account? More than $\$ 102$; exactly $\$ 102$; less than $\$ 102$; don't know; refuse to answer".

5 With the promulgation of the Constitution of Kenya 2010 provinces no longer exist and the province variable has little policy implication.
[79] A Atkinson, S McKay, S Collard, and E Kempson, "Levels of financial capability in the UK," Public Money and Management, vol. 27, pp. 29-36, 2007.

[80] E J Cheron, H Boidin, and N Daghfous, "Basic financial service needs of low-income individuals: A comparative study in Canada," International Journal of Bank Marketing, vol. 17, pp. 49-60, 1999.

[81] S Claessens, "Access to financial services: A review of issues and public policy objectives," The World Bank Research Observer, vol. 21, no. 2, pp. 207-240, 2006.

[82] J. Hogarth, C. Anguelov, and J. Lee, "Why households don't have checking accounts?," Economic Development Quarterly, vol. 17, pp. 75-94, 2003

[83] Ekos Research Associates Inc., Canadian's knowledge and awareness of financial products, services and institutions. Ottawa: Financial consumer agency of canada, 2001.

[84] Patrick Honohan, "Cross-country variation in household access to financial services," Journal of Banking and Finance, vol. 32, pp. 2493-2500, 2008.

[85] Republic of Kenya, The constitution of Kenya, 2010. Nairobi : The Government Printer, 2010.

[86] Leslie Kish, "A procedure for objective respondent selection within the household," Journal of the American Statistical Association, vol. 44, no. 247, pp. 380-387, 1949. 